Chinese Characters 



\section{Chinese Characters}

Profiles of Fast-Changing Lives

in a Fast-Changing Land

EDITED BY

Angilee Shah and
Jeffrey Wasserstrom

Foreword by Pankaj Mishra

甲

UNIVERSITY OF CALIFORNIA PRESS

Berkeley • Los Angeles • London 
University of California Press, one of the most distinguished university presses in the United States, enriches lives around the world by advancing scholarship in the humanities, social sciences, and natural sciences. Its activities are supported by the UC Press Foundation and by philanthropic contributions from individuals and institutions. For more information, visit www.ucpress.edu.

University of California Press

Berkeley and Los Angeles, California

University of California Press, Ltd.

London, England

(C) 2012 by The Regents of the University of California

For acknowledgments of previous publication for chapters 2, 7, 9, II, and I4, please see credits on p. $23 \mathrm{I}$.

Library of Congress Cataloging-in-Publication Data

Chinese characters : profiles of fast-changing lives in a fast-changing land / edited by Angilee Shah and Jeffrey Wasserstrom ; foreword by Pankaj Mishra.

$$
\text { p. } \mathrm{cm} \text {. }
$$

Includes bibliographical references.

ISBN 978-0-520-27026-8 (cloth : alk. paper)

ISBN 978-0-520-27027-5 (pbk. : alk. paper)

I. National characteristics, Chinese. 2. ChinaSocial life and customs. I. Shah, Angilee.

II. Wasserstrom, Jeffrey N.

$\mathrm{DS}_{799 \cdot 4 \cdot \mathrm{C}_{425} 20 \mathrm{I} 2}$

$95 \mathrm{I}-\mathrm{dc} 23$

Manufactured in the United States of America

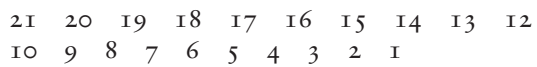

In keeping with a commitment to support environmentally responsible and sustainable printing practices, UC Press has printed this book on Rolland EnviroI00, a I00\% post-consumer fiber paper that is FSC certified, deinked, processed chlorine-free, and manufactured with renewable biogas energy. It is acid-free and EcoLogo certified. 